\title{
Use of Learner Autonomy in Teaching Speaking by Tertiary Level English Language Teachers in Private Universities of Bangladesh
}

\author{
Mariam Jamila \\ Senior Lecturer, Department of English, Bangladesh Islami University, Bangladesh
}

\begin{abstract}
The study has the core aims to investigate the use of learner autonomy in teaching English speaking to the undergraduate students of private universities of Bangladesh. Significant research works worldwide have renowned that use of learner autonomy in tertiary English language classes encourage student incentive and bring noteworthy changes in students' attainment. Therefore, the present study explores teachers' use of learner autonomy in teaching English speaking classes emphasizing various areas of language teaching: setting objectives, selection of materials, methods, evaluation process, learning environment, teacher-student relationship and teacher's role. This study is primarily based on a Likert scale self-report questionnaire survey followed by pilot study and interviews. The subjects in this study are 30 tertiary level English language teachers of four private universities of Bangladesh. The results of the work show that learner autonomy is not yet fully executed by the teachers. The study is anticipated to instigate further effective researches on this field and guide teachers to assume the principles of learner autonomy in English speaking classes at the tertiary level.

Keywords: learner autonomy, teaching English speaking, language teachers, private universities, tertiary level
\end{abstract}

\section{Introduction}

Learning speaking in English has become a burning issue in the pedagogy of Bangladesh. The wide spread use of English in each and every field has increased the demand of learning communication in English. In case of tertiary level English teaching there are some speaking courses which have the purpose to make the learners effective English speakers. But, in maximum cases, at the end of these courses it has been observed that the learners could not overcome their weakness and anxiety and as a result, they could not be efficient English speakers. From the end of $20^{\text {th }}$ century, learner autonomy had been used quiet successfully in teaching second language worldwide. It helps language learners to come out from the usual weakness and anxieties they face while learn a new language as here they take the charge of their own learning. So, this research paper investigates the use of learner autonomy in teaching English speaking classes at the undergraduate level of the private universities of Bangladesh. Holec's (1981) definition of autonomy may clarify the idea further as he describes the term 'autonomy', "the ability to take charge of one's learning' (p. 11). As learner autonomy helps a learner to take charge over own learning, it affiliates him/her more in speaking because this skill carries one of the most important criteria. But, speaking in a second language is always hazardous and problematic to the majority of students. They may be good at learning other skills but 'Speaking" always makes their fingers crossed. Because according to Horwitz (1986), speaking in a second language creates a 'mental block' next to it (p.125). But speaking is a must for the learners. Since, in many contexts, speaking is often the skill upon which a person is judged at face value. In other words, people may often form judgments about our language competence from our speaking rather than from any of the other language skills (Jo Mc Donough and Christopher Shaw, 1993 p.133). So, with immense importance, speaking is being taught at the beginning levels in the private universities of Bangladesh. According to the purpose of Learner Autonomy, it can have an important and successful role in teaching speaking. Learner Autonomy in teaching English focuses on the progress of a learner's confidence and communicative aptitude. Use of learner autonomy has successful contribution in adult education as it gives learners full freedom in learning. Adult learning demands it most as "in order to help learners to assume greater control over their own learning it is important to help them to become aware of and identify the strategies that they already use or could potentially use' (Holmes \& Ramos, 1991, p. 198). So, in autonomous learning every learner gives himself immense importance, he knows that he is the only person here to be charged for learning further. As a result he learns to take responsibility of his own learning. He sorts his own problems out and run for the probable solutions using his own responsibility. This liberty makes an autonomous classroom spontaneous and fruitful where the learners are honored as their psychological faculties are not rigid anymore.

Generally, in all the private universities of Bangladesh English is taught with immense importance. So, the beginning courses are associated with the four skills based ones, Listening and Speaking in English and 
Reading and Writing in English. But the learners face so many hurdles to communicate in English. Because, "Speaking is not the oral production of written language, but involves learners in the mastery of a wide range of sub skills, which, added together, constitute an overall competence in the spoken language." (Jo Mc Donough \& Christopher Shaw, 1993 p.133).

\section{Purpose of the study:}

In the private universities of Bangladesh, English is taught in medium sized classrooms where there are twenty to thirty students. All the classes are teacher fronted and classrooms don't have sufficient modern technology like projector, multimedia and sound system. So many research works have been conducted in the teaching methods pursued in the private universities (Rahman, 2005), there is noteworthy lack of research on the use of learner autonomy in teaching English language in the private universities of Bangladesh though use of learner autonomy is already proved immensely beneficial worldwide. So, a number of researchers have showed that English teaching classrooms are yet dominantly teacher-centered and the use of imported de-contextualized EFL textbooks is alarming.

Though in Bangladesh, teachers are trying a lot to improve teaching methods to facilitate learners and as a result, much works also have been done in Bangladesh in the field of ELT as well as related areas; but it has been observed that there are very few research works on fostering learner autonomy at tertiary level to teach English speaking while it is a major criteria. That is why I am highly interested to work on this topic. In this investigation I will search the use of learner autonomy in six areas of an English speaking class: setting objectives, materials, methods, evaluation, environment and teacher-student relationship in the classroom. This investigation is based on a questionnaire followed by interview conducted among 30 teachers of three private universities of Bangladesh. These universities gave me easy entrance in data collection as I myself am working in one of these universities and the rest two are very familiar to me.

\section{Research Questions:}

The study addresses the following research question in relation to undergraduate education in 3 private universities of Bangladesh:

1. How far learner autonomy is being used in English speaking classes by the language teachers of private universities in Bangladesh?

My research work will be investigating the use of learner autonomy in six basic areas of teaching English speaking - setting objectives, selecting materials, selecting methods, evaluation, environment and teacherlearner relationship.

\section{Significance of the study:}

This study has its significance in many ways. Firstly, the study would provide information on the intensity and understanding of knowledge of learner autonomy possessed by English language teachers of private universities of Bangladesh. This information would extend the further scopes of probable query.

Again this study carries significance because it will give us significant insights about the importance of learner autonomy in teaching English speaking at the tertiary level. This study will also be important for further studies in the field of learner autonomy as it has become a vital need.

The study has immense possibility to offer teachers with key insights about the usefulness of learner autonomy in teaching English speaking classes as well as for teaching all the skills of a new language. Furthermore they will needle their thoughts to use new and diversified methods in adult teaching. This study will bridge up the gap between teachers and learners as well as it will help to make the objectives of a course more fruitful. Teachers and learners will get chance to explore their insight through this study. The newly gained insights will inspire teachers to adopt useful method and plan their lessons making it suitable for learners' involvement more.

This study would make learners aware of their huge potentiality as confident, independent and adult learners to assist them to rewoven their thoughts about modes of learning and walk through a superior world of knowledge through the guidance of their teachers. At the same time the learners will feel their learning as their own asset. It will enhance their sincerity as learners and at the same time it will help to boost up their energy and confidence in learning. Furthermore, this work will open a new horizon in front of the learners showing much honor to their desires, expectations and needs as well as give them splendid chance of using their own potentials. As a result, the learners will feel themselves the most important entity having complete probability which will obviously motivate them to show respect on themselves. Furthermore, all these benefits will enhance a learner's communicative competence in English as well as in all other areas of learning.

Moreover, findings from the study would also be an excellent source of track for course developers to promote autonomous learning in all major areas which are involved in learning a second language including setting objectives, materials, methods, evaluations, environment and so on. This study would be a chance to 
promote thoughts about teaching in autonomous way as far as it is possible. This work will help to add various tasks which will help the learners learn effectively.

Finally, this research work will open other probable doors for further necessary study in this field as research on the use of learner autonomy at the tertiary level is not much available in Bangladesh.

This research paper has been divided into five major sections including introduction. In the second section which is entitled literature review, I will appraise the literature regarding learner autonomy and this section will be followed by theoretical framework devoted to the discussion of the five major areas of investigation which have earlier been mentioned. The third section discusses methodology used in the investigation which includes subjects, instrument and procedure. In the next section I will have discussion on my findings of the data which will be followed by implications. In the last section I will terminate with some recommendation based on my result which will hopefully create some new areas of further research on the same field.

\section{Literature Review}

Learner autonomy is a late twentieth century term introduced by Henri Holec in 1981, who is the father of learner autonomy. Learner autonomy is against all the old, traditional and teacher centered practice of language teaching. It ensures a learner's freedom as an individual one where he learns to think himself important as 'Autonomy is a recognition of the rights of learners within educational system' (Phil Benson). In the field of language teaching there are also some prevailing synonymous terms to autonomy such as, 'independence' (Sheerin, 1991), 'language awareness' (Lier, 1996;James \& Garrett, 1991), 'self-direction' (Candy, 1991), 'andragogy' (Knowles, 1980; 1983) etc., which are near in purpose. The term 'autonomy' indicates to the ability to take charge of own self without being controlled by anyone else. So, learner autonomy is a useful term for an adult learner as it is necessary for him to recognize and solve his own problem. It automatically facilitates a learner's psychology and makes him ready to learn through his own way with better attachment as in autonomous learning, learning is not imposed rather achieved.

- Learner autonomy in teaching language is mainly based on worldwide thoughts and research works of language teachers and researchers Dewey (1996), Holec (1979), Janne (1977), Schwartz (1977), Dickinson (1978), Little (1991), Dam (1990, 1994), Sinclair (2000), Benson (2001, 2007) and many others. All of them talk about the huge potentials of Learner autonomy could be discovered through continuous exercise of it. This way of learning facilitates learners in a self-governing way. This taking charge of own learning widens the scope of positive output where teacher is never the center rather learners get total importance to explore their hidden potentials and interests. It helps a learner sorting out his weaknesses as well as their solutions too. These kinds of activity not only make him a good learner but obviously a responsible and interactive social being as he needs to interact with his all peers. Moreover, in autonomous learning a teacher always remains friendly and works as a facilitator to the learners which create a positive environment of learning. There is nevertheless broad agreement that autonomous learners understand the purpose of their learning program, explicitly accept responsibility for their learning, share in the setting of learning goals, take initiatives in planning and executing learning activities, and regularly review their learning and evaluate its effectiveness ( Holec 1981, Little 1991). So, all these aspects make learning a spontaneous, purposeful and prolific process and thus learner autonomy gets the place of uniqueness.

According to Littlejohn (1997), learner autonomy has following basic principles:

1. Learner autonomy shifts its focus from teaching to learning.

2. Learners themselves plan to make set objectives.

3. Learners have full freedom in monitoring their progress.

4. Learners evaluate their learning by themselves where self-assessment and peer evaluation get importance.

5. Learners are free to select their learning strategies according to their needs and goals.

6. There is a total chance to reshape approaches and procedures for optimal learning.

7. In an autonomous classroom, a teacher is always a friend.

8. A teacher is a facilitator too as he/she adapts materials, methods and other supports to the learners according to their needs.

9. An autonomous classroom always provides an easy, comfortable and non-threatening climate.

(Benson and Voller, 1997, p.181-182)

All the characteristics are showing that an autonomous learning is obviously learner centered. It gives importance on a learner's self. So, in autonomous learning, learning becomes accomplishment. Teachers become friends to the learners and this state makes learning easier and at the same time, peers also get importance as they asses learning. This positive environment enhances learning as learners get freedom, importance and respect from teachers.

According to O'Malley and Chamot (1990), learner autonomy has cognitive strategies which make learners autonomous and a responsible, conscious and complete social entity. This strategy helps a learner to grow his confidence and lessens his dependence on a teacher. So, an autonomous classroom has autonomy in 
every area of learning as setting objectives, choosing materials, selecting methods, assessing results as well as having a positive learning environment where a sound and friendly teacher-student relationship is mostly mandatory.

In a language class, an objective is always set to know a clear goal to be gained at the end of the program. According to Holec (1979,) learners will know his objectives and will make his own assessment which further will help him to know the appropriateness of his applied methods. On the other hand, the picture of a traditional class room is totally different where learners don't set their objectives. As a result, learners fail to create psychological tie with learning. So, discarding emotion, learning becomes fruitless as it is mentioned that in a "traditional classroom," teachers are the purveyors of knowledge and wielders of power, and learners are seen as 'container[s] to be filled with the knowledge held by teachers' (ibid.). if learners set their objectives then they will learn to care it which would create attachment in achieving the goal as it is mentioned again, knowledge is something 'built up by the learner' (von Glasersfeld \& Smock, 1974; cited in Candy, 1991;270). So, learners should be allowed to set their learning objectives and to opine about their feelings.

Learner autonomy allows learners to select their learning materials which widens scope to employ own experience. According to Tumposky (1982), own selected materials create interest and courage in learners mind as individual learners differ in their choice, ability, needs and needed practice. So, choosing own material makes them responsible and sincere to the learning process and thus they take charge of self-learning. It helps to make them confident and creates self-respect. At the same time, while choosing materials, learners become decision makers and this unconventional situation widens their scope to be active in participation.

After selecting own materials, autonomous learners are always allowed to go for self directed learning methods. This process will take them to the appropriate methods step by step. Autonomous learning process will lead them to success through errors and corrections (Holec, 1981). Adult learning is quiet "risky and difficult business" according to the present context,( Krashen, 1981) and this theory is totally applicable to the learners of the private universities as they all belong to the same stage. So, autonomous learning can be fruitful in this field of adult learning. Because, self directed methods creates psychological involvement of the learners to the learning process as it is mentioned that learner autonomy is 'essentially a matter of the learner's psychological relation to the process and content of learning--a capacity for detachment, critical reflection, decision-making, and independent action' (Little, 1991, p. 4). Instead of it, traditional learning process imposes on a learner discarding interest where he never response rather reacts to the teacher (Boud, 1988; Kohonen, 1992; Knowles, 1975). So, where there is a sharp difference between responding and reacting there learning cannot be expected. Choosing own strategies helps a learner in sorting out his own 'leaning and acquisition rhythm' where he also learns to give pace according to his need (Holec, 1981).

In an autonomous classroom, teacher is always a friend to facilitate the learners and to make the learners accessible to their potentials and make learning a successful journey. In an autonomous learning process, teachers are always mentioned as positive figures in the classroom who work as 'helping hands' and this attitude makes learners independent and reliefs them from dependency (Sheerin, 1997, cited in Benson \& Voller, 1997, p. 63). So, finally an autonomous class shifts a teacher-centered classroom into a learner-centered one. Teachers become facilitator and learners feel safe and can easily rely on them without being much tensed.

A learner's self assessment is emphasized in an autonomous classroom which protects him from the traditional and superficial evaluating process. Dumping this external process, autonomous learning makes learning 'an internal part' which is the most mandatory part of any achievement (Stanchina and Holec, 1977). This internal trial makes a learner aware of making real difference in between what he has already achieved and what he needs to gain further. Evaluation is a big part of responsibility in autonomous learning which requires a learner's real self-evaluation. Self-evaluation will create link to the other self guided steps as it has been taken in case of objectives, materials, methods and strategies. So, at the same time the total learning process will get a complete shape as it has been mentioned in learner autonomy that without self-evaluation, learner autonomy is incomplete (Oskarsson, 1980). It is too logical that when all the areas are self-motivated then evaluation also automatically becomes an unavoidable part in learner autonomy (Stanchina, 1985).

Autonomous learning environment does not mean a comfortable classroom only rather, it has a lot to include inside. First of all, learner autonomy aims to create a non-threatening environment in language learning. Learners feel ease which supports them to enhance learning and to use their probabilities to the fullest extent. Here, a teacher works always as a facilitator providing the learners vast materials to choose, needed tools, equipments, proper guidance and support which will create their interest as well as will bring out the learners' maximum proficiency, (Murray, 2009).

So, combination of all the above aspects will create attachment of learners to the learning process. Through this way, when learners would feel the entire learning process of their own which will help removing mental blocks, rigidity, fear and barriers. As a result fruitful output will automatically come out as it is mentioned 'learning is affected by how students feel about themselves' (Moskowitz, 1978). 
From the overall discussion we can encapsulate that an autonomous class have the following basic characteristics:

- Learners are aware of their goal by setting their objectives themselves.

- Learners enjoy full freedom in selecting materials according to their objectives utilizing their own experiences.

- Learners choose their own strategies to sort out the right ones by applying multiple methods and then selecting and rejecting.

- Learners are allowed to do self-assessment.

- Teacher is always a guide and facilitator.

- All learners are equal and get importance and respect from teacher.

- Non-threatening climate or positive environment promotes learning easily.

So, worldwide research on learner autonomy has proved its high demand in the field of language teaching. In Bangladesh too, this is the high time to investigate the scope of implementing learner autonomy. So, here exists my interest to investigate that how far learner autonomy is used in English speaking classes in the private universities of Bangladesh. I would like to work on it and to create some further fields to work with.

\section{Theoretical Framework}

In this study 'learner autonomy' stands for the basic and general characteristics of learner autonomy in teaching speaking skill to the second language learners. The main focal point of this research is to look into whether or to what extent teachers of the departments of English of the private universities of Bangladesh use the similar characteristics in their undergraduate English speaking classes. The study is based on the theory of learner autonomy (Schwartz, 1977; Dickinson, 1978; Holec 1979 ) which has its focus on a learner's taking charge of his own learning where he is the major entity to be concerned about all the aspects of his learning. This kind of taking charge helps learners to take learning as his own asset which psychologically sets him to reach the aim and at the same time increases their intellect and knowledge as well as their academic excellence in language learning. All these factors are very important in language learning specially in case of learning speaking as it is discussed before. Under this perspective, this inquiry will be limited to the six areas: setting objectives, materials, methods, evaluation, teacher-learner relationship and learning environment.

\subsection{Setting Objectives:}

As autonomous learning is a self-directed learning so, here the learner himself defines his objectives and other essential consequence of this will be the introduction of the learner's specific personal dimension (Holec, 1979). According to Holec (1979), Definition of the objectives will be based on an analysis made by the learner of the final behavior aimed at, in accordance with his subjective criteria (p.10) .

So, in case of earning communicative competence the learner rather needs to learn something to use in his own cultural context, not to learn the native speaker's context. Through setting the objective a learner wants to develop a meaningful self and 'future speaker' in other language where he will get the magnitudes 'attitude towards the other person', 'personal involvement', 'image of oneself', etc,' all of them expressed by verbal behavior, are naturally an integral part of communication' (Holec, 1979, p.14). So, in an autonomous learning process, a learner fixes his objectives according to his own needs and at the same time he has the right to change it according to his ability and desire.

\subsection{Materials}

Choosing material is closely related to setting objectives. An autonomous learner selects his materials according to his choice and interest which he thinks will help him to reach his objective. According to Holec (1979), 'the themetic contents are of course determined on the basis of personal choices and not on the basis of the choices of the majority of the class-group or the subjective choices of the teacher' (p.13). In this regard, learners even can change and modify their materials frequently. So, in this process, a fixed material for all is definitely not in use rather an autonomous classroom has variations of material from a wide range of collection. Holec (1979) also defined the term with more thoughts as he says, 'contents are no longer 'brought in' from outside but are to some extent 'created' by the learner. He will have to discover those contents by observing and analyzing the source of information available to him: written texts, sound recordings, video recordings, films, dictionaries, grammars, etc. These sources will also include both educational and authentic documents, and native speakers (p.14). So, materials for learning speaking should depend on a learners expected communicative competence on his desired situations. Such as some materials can have focus on professional purpose where some others may serve other purpose related to practical life related oral communications. 


\subsection{Methods}

The nature of materials in an autonomous classroom is almost same as the materials mentioned above. So, methods are not imposed on the learners, they have full freedom in choosing their methods. They learn thorough the activities which seem interesting to them. In this case, if the tasks given by the teachers are interesting or related to their practical life experience, they do that. According to Holec (1979), 'the learner himself will be defining his methods and techniques' (p.15). So, according to the theory of an autonomous classroom, learners can learn speaking through different activities. Such as, some may like to learn through role play, some may like to learn through debate and in other case it may happen through pair work.

\subsection{Evaluation:}

As autonomous learning depends on a learner's self, so 'Evaluation is an autonomous learning scheme' ( Henner-Stanchina, et al., 1977). In autonomous learning process, objectives, materials and methods all are interrelated and each one is following the other one. So, materials and methods are set according to the objective set by the learners. In the same way, evaluation also has to be considered according to the fulfillment of objective. According to Holec (1979), learner autonomy talks about self-evaluation, which is not to find out the linguistic ability gained by the course content, rather to decide how far the results are achieved are equal with the learner's objective p.160. So, self-assessment and peer evaluation enhance the desire of learning and make the total learning process an effective and fruitful one.

\subsection{Teacher-Learner Relationship:}

Though there is no best way to teach, some ways in which teachers relate to learners are more likely to promote engagement, learning, achievement, and wellbeing than are other ways (De Wolff \& Van Lizendoorn, 1997; Kochanska, 2002; Main, Kaplan, \& Cassidy, 1985). In an autonomous learning process, a teacher is always a facilitator. In this case, teachers always maintain a high quality relationship with the learners. So, the relationship becomes so sound that the learners get full effort from their teachers about what they want and need. In this sort of relation, teachers always give the learners enough paces to think, to ask questions, to motivate themselves to the next attempt to their own learning and all these steps promote the learning process. In learner autonomy, teachers are the facilitators of their learners' inner motivation as well as their potentials.

\subsection{Learning Environment}

Including greater perceived competence (Deci et al., 1981), higher mastery motivation (Ryan \&Grolnick, 1986), enhanced creativity (Koestner, Ryan, Bernieri, \& Holt, 1984), a preference for optimal challenge over easy success (Shapira, 1976), increased conceptual understanding (Benware \& Deci, 1984), active and deeper information processing ( Grolnick \& Ryan, 1987), greater engagement (Reeve, Jang, Carrel, barch, \& jeon, 2004), positive emotionality (Patrick, Skinner, \& Connell, 1993), higher intrinsic motivation (Reeve, Nix, \& Hamm, 2003), enhanced well-being (Black \& Deci, 2000), better academic performance (Boggiano, Flink, Shields, Seelbach, \& Barrett, 1993), and academic persistence rather than dropping out of school (Vallerand, Fortier, \& Guay, 1997). So, in learner autonomy, learning environment plays a vital role for. An autonomous learning environment is a must in learning English speaking as it was mentioned before, "In a foreign language, a speaker has to look for suitable lexis, has to construct an appropriate syntactic structure and needs to use a comprehendible accent, plus the demanding tasks of thinking and organizing ideas and expressing them at the same time (Daly 1991, p. 1). So, multiple activities are involved in speaking and for this reason, high comfort in classroom is mandatory to produce all these simultaneously without hesitation.

\section{Methodology}

This study has the objective to examine teachers' use of learner autonomy in teaching English speaking at Bangladeshi private universities. As the research instrument the study was primarily based on a questionnaire survey followed by semi-structured telephone interview.

This chapter is to describe the methodology which includes research design, pilot study, subjects, two research instruments (likert scale questionnaire and semi structured telephone interview), procedures of data collection and data analysis.

\subsection{Research Design}

This research is an exploratory study based on mixed-method model. I have used a questionnaire for collecting quantitative and qualitative data because it is an easy way to collect a wide range of data from a large sample within a short time. So, in this mixed method model I have collected both qualitative and quantitative data (Tashakkori and Teddlie, 2003). In order to fulfill my purpose, I have used a five-point Lickert scale questionnaire to collect quantitative data and semi-structured telephone interviews for collecting qualitative data. 
Questionnaire survey is used in this study because of some advantages as by using this questionnaire survey, data can easily be collected from a large number of participants (Dillman, 2000). At the same time, I am aware of some probable disadvantages of questionnaires which may sometimes produce inaccurate data; it was the best possible option for me to collect data from the private universities of Bangladesh.

On the other hand, I also have used semi-structured telephone interviews as it is necessary to collect qualitative data. According to Bogdan and Biklen, qualitative research is concerned with the process rather than simply with outcomes or products (2007). There are many modes to conduct qualitative survey, but I have used semi-structured telephone interview because of its advantages. For example, in semi-structured telephone interview, it is possible to get data easily within a very short period. At the same time, it gives a researcher much scope to clarify unclear questions to the interviewee, to ask further leading questions, to organize and oversee easily (Wilkinson and Birmingham, 2003).

For all these reasons, in this research, I have used a mix-method design. This mixed method to agree on the use of learner autonomy has also been used by other researchers (Wilhem and Pei, 2008; Bridge, 2006).

\subsection{Pilot Study}

While using a questionnaire survey, pilot study becomes important to judge the strengths and weaknesses of the questionnaire (Dillman, 2000). For this study, I have accomplished a pilot study with eight English language teachers who did not participate in the main study. I asked them to answer the questionnaire as well as to give feedback on the questionnaire items. I also asked them to write if there is any confusion. The teachers found the questions 'easy' to understand and to respond. The length of the questionnaire was quiet moderate although some teachers reported it to be "long but easy". It took approximately 25 minutes to answer the questions. So, the total number of items (30) in the final questionnaire was not changed as in the pilot questionnaire. Some words and phrases were considered as difficult and confusing were reshaped and transferred into simpler to understand without facing trouble. As a whole, the participants in the pilot study found the questionnaire easy and simple to answer.

The semi-structured interview questions have also gone through close revision and examination to increase authority and aptness of the interview in this research.

\subsection{Subjects}

The subjects in this study were 30 English language teachers of three major private universities in Bangladesh. Among the teacher participants, ten were females and twenty were males. Participant teachers were randomly from three private universities: one is Bangladesh Islami University, Bangladesh (BIU), the second one is Northern University Bangladesh (NUB) and the last one is Primeasia University, Bangladesh (PU). The reason behind choosing Bangladesh Islami University is that for long five years I have worked as a faculty of that institution and I have been familiar with all the language teachers here. Again, Northern University and Primeasia University both are two renowned universities of Bangladesh.

\subsection{Instruments}

The questionnaire which has been used here is basically designed by Wilson (2005). The questionnaire is designed to measure the use of learner autonomy by language teachers in teaching English speaking to the adult learners of the private universities of Bangladesh. Wilson (2005) here created a suitable, trustworthy and psychometric measurement tool that measures six process elements for adult teaching. The questionnaire items were modified considering the context of Bangladesh as well as the competence level of the learners of this country. In order to prepare the complete procedure, effective feedback were taken several university teachers of Bangladesh and all the opinions were taken into consideration.

I used only one version of the questionnaire and that was for the teachers (see appendix-1 for teacher questionnaire). This questionnaire is consisted of only one section which is designed to bring forth the use of learner autonomy in English speaking classes with adult learners. This part is divided into subgroups like setting objectives (5 items), learning materials (5 items), learning methods (5 items), evaluation (5 items), teacherlearner relationship (5 items) and environment (5 items). All the items were designed following five-point Likert Scale ranging from strongly agrees to strongly disagree. Teachers were asked to express their beliefs and to give their open views about the teaching strategies they are currently following in English speaking classes. All the responses were rated as strongly disagree $=1$; disagree $=2$, not sure $=3$, agree $=4$ and strongly agree $=5$.

\subsection{Semi structured telephone interview}

I have collected qualitative data through semi-structured telephone interview with five selected participants who were five language teachers. These teachers were selected from the survey participants as they were highly interested to go through the interview over telephone. The questions asked to the teachers were 
specific and focused information regarding their beliefs and views about the use of learner autonomy in the English speaking classes with adult learners.

In the interview, of semi-structured questions were planned to seek the information about the teachers use of learner autonomy in English speaking classes. Therefore, the interview questions covered most of the areas of learner autonomy as it is advocated by Holec (1979).

I have used semi-structured telephone interview in this study because of some advantages. For example, through this interview questions it is far easy to conduct; at the same time, if any question is not clear, then participants get chance to ask for clarity. According to Wilkinson and Birmingham (2003), semi-structured telephone interviews are considered as the best used for less time consuming and much focused interviews. Furthermore, telephone interview has the advantage of collecting data within a very short time period as many more people can be interviewed by telephone in the time it would take to perform just one face- to-face interview.

However, I was aware of the probable disadvantages of telephone interview as well. I also know that this process is quiet less personal than face-to-face interview and all the gestured data are lost. Yet, as I am pretty busy with my job and my colleagues are also not able to give me time during office hour, face-to-face interview is quite unmanageable for me. For this reason, I took interview through using mobile phone. The total interview procedure gave me satisfactory chance to listen to the teachers' opinion and problems and to ask the participants further necessary questions. Respondents were co-operative, comfortable and they did not express any anxiety or nervousness through which they could have undergone during a face-to-face interview.

Though the telephone interview has some advantages, I was completely aware of some probable disadvantages of using it too. Such as, after the interview I had to transliterate the data which can be exactly not similar to what they said and meant. There was another problem regarding teachers' lack of confidence in speaking English. I had to repeat some questions as they failed to understand properly at the first time. Another problem was regarding their expression as sometimes they could not express their thought which they might produce if I asked them to write.

\subsection{Procedure of data collection}

I collected both qualitative and quantitative data by using a questionnaire survey and through a semi structured telephone interview.

Firstly, the questionnaires were distributed to the teachers of two different universities by two of my colleagues and they also explained the purpose of the survey. The third university was the one where I am working presently. So, all the questionnaires were distributed and collected properly later on.

The following table has a clear presentation of different stages of data collection which includes instrument preparation as well:

\begin{tabular}{|l|l|}
\hline \multicolumn{2}{|c|}{ Table: Instruments preparation and data collection procedures } \\
\hline No & Stages \\
\hline 1 & A 30-item Likert scale questionnaire based on Wilson (2006) is developed. \\
\hline 2 & A semi-structured interview questions are prepared. \\
\hline 6 & The questionnaire and semi-structured interview questions are revised. \\
\hline 7 & The questionnaire is pilot tested by the participants who did not take part in main research. \\
\hline 8 & The questionnaire is revised and further modified based on the feedback from the pilot survey. \\
\hline 9 & The questionnaires and generic consent forms for participants are emailed to the participants. \\
\hline 10 & Teachers' questionnaires are e-mailed to the teachers of those three particular universities. \\
\hline 11 & $\begin{array}{l}\text { Semi-structured interview questions are asked to five participants (5 teachers) who showed their interest to participate } \\
\text { in follow up interview. }\end{array}$ \\
\hline
\end{tabular}

\subsection{Method of data analysis}

All the quantitative data in this survey is analyzed using the Statistical Package for Social Sciences (SPSS version 16.0). For descriptive statistics frequencies and means are calculated for each item.

The open-ended qualitative data generated from telephone semi-structured interviews are analyzed by using strategies of coding and identifying common themes. Coding strategies are basically "the means of sorting the descriptive data collected so that the material bearing on a given topic could be physically separated from other data" (Kabilan and Kamaruddin, 2010, p. 141). The participants' direct used words were in use to present and discuss the findings. The findings of the interview data helped a lot to interpret the results of quantitative data as there was scope to ask for further clarification. 


\section{Data Analysis and Discussion of Findings:}

This study has the core aim to investigate Bangladeshi tertiary level teachers' practices about the use of learner autonomy in English speaking classes. In order to complete the research both qualitative and quantitative and qualitative data were collected by using self-report Likert scale questionnaire and semistructured telephone interviews. This chapter clearly presents results and discussion of the findings of both quantitative and qualitative data. Results of the participants' responses are presented through the order of research questions. Findings are also vividly discussed in relation to the numerous studies reviewed in the study earlier.

1. Research question: How far learner autonomy is being used in English speaking classes by the language teachers of private universities in Bangladesh?

The investigation will be done about the use of learner autonomy in the following six basic areas of teaching English speaking skill:

i) Setting objectives

ii) Selecting materials

iii) Selecting methods

iv) Evaluation

v) Environment

vi) Teacher-learner relationship

\subsection{Planning and Setting of Objectives:}

In an autonomous learning process learners are mostly involved in setting their objectives according to their needs. According to Holec, in case of learning speaking in English the learner will decide like "I must be capable of doing this in conversation with such and such a speaker, in such and such a sphere..." (1979). But, the result in Table-1 reveals that only (26.7\%) respondents admit that they decide the learning objectives for the learners where as a noticeable number of respondents (86.67\%) allow that learning objective is decided by the institution itself which is not congruent to the current trend or belief of learner autonomy. Another important matter is revealed through the table that most of the teachers don't negotiate about the learning objectives with the learners and that is a complete clash with the ideas of learner autonomy. Even, half a number of the total student is not fully aware of the learning objectives while approximately $(36.67 \%)$ are confused about sharing objectives with the learners. So, the findings in Table-1 indicate that teachers can not promote learner autonomy in setting objectives for the speaking classes. The possible reason for this may be that the universities don't allow the learners to set their objectives as it is decided by the syllabus of the institution as a large number of respondents $(86.67 \%)$ allow that. But, teachers can work more to inspire the learners to set their objectives as far as it is possible for them. This result indicates that Bangladeshi tertiary level teachers are still guided by sort of teacher-centered learning strategies.

Table-1 Teacher Questionnaire Results: Planning and Setting of Objectives

\begin{tabular}{|l|l|l|l|l|l|l|l|}
\hline No & Statements & 5 & 4 & 3 & 2 & 1 & $\mathrm{M}$ \\
\hline 1 & $\begin{array}{l}\text { I decide the learning objective of } \\
\text { the learners. }\end{array}$ & 10 & 16.7 & 10 & 46.67 & 16.67 & 2.57 \\
\hline 2 & $\begin{array}{l}\text { I inspire the learners to fix their } \\
\text { learning objective according to } \\
\text { their goal of speaking by } \\
\text { themselves. }\end{array}$ & 3.33 & 20 & 6.67 & 56.67 & 13.33 & 2.43 \\
\hline 3 & $\begin{array}{l}\text { I negotiate learning objectives with } \\
\text { learners. }\end{array}$ & 3.33 & 33.33 & 30 & 26.67 & 6.67 & 3.00 \\
\hline 4 & $\begin{array}{l}\text { The learning objective is decided } \\
\text { beforehand by the speaking syllabus of the } \\
\text { institution. }\end{array}$ & 30 & 56.67 & 6.67 & 3.33 & 3.33 & 4.06 \\
\hline 5 & $\begin{array}{l}\text { Learners are fully aware about their } \\
\text { learning objective. }\end{array}$ & 3.33 & 10 & 36.67 & 46.67 & 3.33 & 2.63 \\
\hline
\end{tabular}

\subsection{Material:}

The results in table-2, show that a large number of teachers do not decide the materials by their own. $(20 \%)$ of them are diverged in their opinion whether they should allow the learners to decide their learning materials. About (63.34\%) teachers allow that the materials are decided by the institution whereas $(13.33 \%)$ decides the material. Learner autonomy promote the learners to create the materials by themselves according to their need and desire where the results show that $(80 \%)$ of the teachers allow that materials are never created rather brought in to the classroom. 
Another noticeable finding is that $(90 \%)$ of the respondents allow that the materials are same for all the learners and $(80 \%)$ of them allow that the materials are not different for different ability students. On the other hand, learner autonomy has the belief to promote all the learners to select their materials according to their ability and areas of interest. Therefore, the results confirm that learner autonomy is almost absent in case of selecting materials. The possible reason for this may be that the universities do not allow them to select materials by themselves and at the same time they don't allow the learners to create their materials according to their need and interest.

Table-2 Teacher Questionnaire results: Learning material

\begin{tabular}{|l|l|l|l|l|l|l|l|}
\hline No & Statements & 5 & 4 & 3 & 2 & 1 & M \\
\hline 6 & $\begin{array}{l}\text { I decide on all materials for learning speaking for } \\
\text { learners }\end{array}$ & 3.33 & 3.33 & 20 & 70 & 3.33 & 2.33 \\
\hline 7 & $\begin{array}{l}\text { The speaking materials are decided by the } \\
\text { syllabus of my institution. }\end{array}$ & 26.67 & 36.67 & 23.33 & 10 & 3.33 & 3.73 \\
\hline 8 & $\begin{array}{l}\text { Learners speaking materials are not brought in' } \\
\text { but created by the learners themselves. }\end{array}$ & 3.33 & 6.67 & 10 & 70 & 10 & 2.23 \\
\hline 9 & $\begin{array}{l}\text { Learning list varies from learners to learners } \\
\text { according to their own interest area of speaking. }\end{array}$ & 3.33 & 6.67 & 76.67 & 13.33 & 2.00 \\
\hline 10 & $\begin{array}{l}\text { Learner materials are for different speaking } \\
\text { purpose different for different ability students. }\end{array}$ & 0 & 6.67 & 13.33 & 53.33 & 26.67 & 2.00 \\
\hline
\end{tabular}

\subsection{Methods:}

According to learner autonomy, the learning activities should be selected by the learners as this is a self-directed learning (Holec, 1979). The finding in table-3 shows that almost all the teachers (90\%) admit that the learners are not allowed to decide their learning strategies according to their interest on different communicative areas. Therefore, the teachers are not going through autonomous teaching methods. Moreover, a large number of teachers (93.33\%) give same amount of time to all the learners for their speaking activities. This finding is similar to the finding of Hasan and Akanda (2009) who also observe that in the universities learners are taught English in the same way and also got same quantity of time for completing the tasks.

So, the finding of this table shows that teachers do not admit the learners to choose their own strategies which principle is a strong barrier in case of learning English in an adult age according to the belief of learner autonomy. Another noticeable finding is that a almost all the teachers (90\%) admit that the pace of learning is decided by them whereas it directly clashes with autonomous learning principles. So, the teachers should encourage the learners to engage them in selecting their own desired strategies of learning which can make a positive output in learning English speaking.

Table 3: Teacher questionnaire results: Learning method

\begin{tabular}{|c|c|c|c|c|c|c|c|}
\hline No & Statements & 5 & 4 & 3 & 2 & 1 & $\mathrm{M}$ \\
\hline 11 & $\begin{array}{l}\text { I follow the same teaching method for teaching } \\
\text { speaking to my learners. }\end{array}$ & 16.67 & 60 & 10 & 10 & 3.33 & 3.77 \\
\hline 12 & $\begin{array}{l}\text { Learners decide their learning strategies according to } \\
\text { their interest on different communicative areas. }\end{array}$ & 0 & 3.33 & 6.67 & 63.33 & 26.67 & 1.87 \\
\hline 13 & $\begin{array}{l}\text { I give same amount of time to all learners for doing } \\
\text { speaking activities. }\end{array}$ & 43.33 & 50 & 6.67 & 0 & 0 & 4.37 \\
\hline 14 & $\begin{array}{l}\text { Assignments for learning speaking are different for } \\
\text { different ability students }\end{array}$ & 0 & 6.67 & 10 & 50 & 33.33 & 2.13 \\
\hline 15 & $\begin{array}{l}\text { I decide the pace of learning according to the pace of } \\
\text { learners' acquisition in speaking. }\end{array}$ & 33.33 & 56.67 & 6.67 & 3.33 & 0 & 4.13 \\
\hline
\end{tabular}

\subsection{Evaluation:}

In an autonomous language learning process, it is encouraged to involve the learners in the process of evaluation and also in grading by themselves or by their peers. But, it is remarkable to note that all most all the teachers $(93.33 \%)$ evaluate the learners' works by themselves. So, this finding shows that there is lack of 'responsible learning' (Patterson, 1977). Another noticeable finding is that, more than half teachers $(66.67 \%)$ negotiate with the learners about how their acquired learning on speaking will be assessed. It proves that, the teachers of Bangladeshi universities want the learners' involvement in evaluating their tasks by themselves. On the other hand, only a few teachers (13.33\%) allow their learners to evaluate their tasks by themselves. Though this is a poor amount but it shows the presence of autonomous learning to some extent. This result also shows the possibility that this amount can be promoted in future.

This finding also reveals the process of evaluation practiced by the university teachers in Bangladesh. The probable reason behind this may be the institutions do not allow the learner to assess their tasks by themselves as there is lack in efficiency. 
Table4: Teacher Questionnaire results: Evaluation

\begin{tabular}{|l|l|l|l|l|l|l|l|}
\hline No & Statements & 5 & 4 & 3 & 2 & 1 & $\mathrm{M}$ \\
\hline 16 & Evaluation method is same for all students. & 66.67 & 33.33 & 0 & 0 & 0 & 3.00 \\
\hline 17 & I myself evaluate learners' works. & 50 & 43.33 & 6.67 & 0 & 0 & 4.43 \\
\hline 18 & $\begin{array}{l}\text { I negotiate with the learners how their } \\
\text { acquired learning on speaking will } \\
\text { be assessed. }\end{array}$ & 20 & 46.67 & 10 & 16.67 & 6.67 & 3.57 \\
\hline 19 & $\begin{array}{l}\text { I allow learners to evaluate their own } \\
\text { speaking tasks by themselves. }\end{array}$ & 0 & 13.33 & 10 & 56.67 & 20 & 0.17 \\
\hline 20 & $\begin{array}{l}\text { The testing method on the speaking skills } \\
\text { varies according to learners' ability. }\end{array}$ & 0 & 0 & 6.67 & 43.33 & 50 & 1.57 \\
\hline
\end{tabular}

\subsection{Environment:}

The result of Table-5 shows the most noteworthy amount that all the teachers $(100 \%)$ admit that they respect the students' views and emotion which is playing one of the most important role in autonomous learning process. Furthermore, all most all the teachers $(90 \%)$ create an informal and relaxing environment in the class which is one of the major principles of learner autonomy.

In Table-5, we find a diverging opinion as it is very contrastive to note that majority of the teachers $(80 \%)$ is not working as co-learners with their learners. Simultaneously, this is also noteworthy that more than half teachers $(70 \%)$ don't allow the learners to debate or challenge with the ideas they are carrying with themselves. So, the result indicates that, though the teachers create relaxing environment in the class and also respect the learners personal views and emotion, they are at the same time too traditional in allowing the learners to debate and challenge with the teachers own views. Most of the university teachers are carrying the strategy not to be co-learners with the teachers which is contradictory with the principles of learner autonomy. So, this result clearly shows the picture that, in case of creating positive environment, some important steps are yet to take by the teachers.

Table- 5 Teacher Questionnaire Results: Environment

\begin{tabular}{|c|c|c|c|c|c|c|c|}
\hline No & Statements & 5 & 4 & 3 & 2 & 1 & $\mathrm{M}$ \\
\hline 21 & $\begin{array}{l}\text { I create an informal and relaxing environment in } \\
\text { the class. }\end{array}$ & 26.67 & 63.33 & 10 & 0 & 0 & 4.17 \\
\hline 22 & I work as a co-learner with the learners. & 0 & 6.67 & 13.33 & 36.67 & 43.33 & 1.43 \\
\hline 23 & Learners decide the learning environment & 0 & 0 & 6.67 & 33.33 & 60 & 1.47 \\
\hline 24 & $\begin{array}{l}\text { I respect every student's views, emotions and } \\
\text { feelings. }\end{array}$ & 43.33 & 56.67 & 0 & 0 & 0 & 4.43 \\
\hline 25 & $\begin{array}{l}\text { I allow learners to debate/ challenge/disagree with } \\
\text { their (teachers') ideas. }\end{array}$ & 6.67 & 13.33 & 10 & 53.33 & 16.67 & 2.4 \\
\hline
\end{tabular}

\subsection{Teacher-Learner Relationship:}

The results of table- 6 show that $100 \%$ teachers are co-operative and friendly with the learners and the same amount $(100 \%)$ help the learners to overcome their fear in speaking which is very important in adult learning. This picture is very positive as it shows that there is a very sound relation between the teachers and the learners in Bangladesh. Some other results show that $93.4 \%$ teachers always meet the learners outside the class to solve their problems which attitude clearly indicates that the teachers maintain a counseling hour for the learners. Another noteworthy and positive matter is that $100 \%$ teachers tell the learners to avoid negative thinking and attitude in case of learning English speaking and this positive picture is one of the important features in learner autonomy. This also proves that the teachers nurture the affective filters of the learners (Patterson, and Richards and Rodgers 2001).

Table- 6 Teacher Questionnaire Results: Teacher-Learner relationship

\begin{tabular}{|l|l|l|l|l|l|l|}
\hline No & Statements & 5 & 4 & 3 & 2 & 1 \\
\hline 26 & I am friendly and co-operative with the learners & 53.33 & 46.67 & 0 & 0 & 0 \\
\hline 27 & $\begin{array}{l}\text { I help the learners to overcome their fear in speaking } \\
\text { English. }\end{array}$ & 70 & 30 & 0 & 0 & 0 \\
\hline 28 & $\begin{array}{l}\text { I meet the learners individually outside the class hours to } \\
\text { solve their problems. }\end{array}$ & 26.67 & 66.67 & 6.67 & 0 & 0 \\
\hline 29 & $\begin{array}{l}\text { I speak less and encourage the learners to speak in English } \\
\text { more in the class }\end{array}$ & 26.67 & 63.33 & 10 & 10 & 0 \\
\hline 30 & $\begin{array}{l}\text { I tell the learners to avoid negative thinking and attitudes } \\
\text { regarding English speaking }\end{array}$ & 83.33 & 16.67 & 0 & 0 & 0 \\
\hline
\end{tabular}




\subsection{Top five practices of the teachers:}

It is very interesting to notice that the top five practices of the teachers are diverged in the results. Firstly, it is very positive and hopeful to find in table- 7 that, teachers strongly and mostly practice for item-30 $(\mathrm{M}=4.83)$ and this is followed by item-25 $(\mathrm{M}=4.53)$, where teachers are very friendly and co-operative with the learners. This result shows that, teachers always try to keep a sound relation with the learners. This practice also creates a relaxing learning environment which is one of the most important principles of learner autonomy.

On the other hand, it is also noteworthy that item-17 is vastly practiced by the teachers. This practice gives emphasize on the teachers own evaluation and at the same time the practice for item-13 is also important where same amount of time is allocated for all the learners. These both practice are opposite about the process principles of learner autonomy. As, according to Holec, "In self-directed learning the student decides for himself when to study, how long to work at a time, and he can therefore adjust his learning rhythm to his acquisition rhythm (1979)."

Table-7

\begin{tabular}{|l|l|l|c|}
\hline No & $\begin{array}{l}\text { Practice } \\
\text { items }\end{array}$ & Statements & M \\
\hline 1 & 30 & $\begin{array}{l}\text { I tell the learners to avoid negative thinking and attitudes regarding English } \\
\text { speaking. }\end{array}$ & 4.83 \\
\hline 2 & 25 & I am friendly and co-operative with the learners. & 4.53 \\
\hline 3 & 17 & I myself evaluate learners' works. & 4.43 \\
\hline 4 & 24 & I respect every student's views, emotions and feelings. & 4.43 \\
\hline 5 & 13 & I give same amount of time to all learners for doing speaking activities. & 4.37 \\
\hline
\end{tabular}

\subsection{Bottom five practices of the teachers:}

The findings from table-8 reveal that item no-19, 'I allow learners to evaluate their own speaking tasks by themselves' have the lowest mean (0.17). This finding shows that teachers yet believe in traditional teaching method which does not allow the learners to evaluate their own works. Again, 'I work as a co-learner with the learners' (item-22, $\mathrm{M}=1.43$ ), 'learning list varies from learners to learners according to their own interest area of speaking, (item-9, M=2.00)-these practices also have very low means which clearly indicates the low practice of learner autonomy in teaching speaking classes at the tertiary level in Bangladesh. So, it really a very lot to done yet to have autonomous teaching practice for English speaking classes.

Table-8

\begin{tabular}{|l|l|l|c|}
\hline No & $\begin{array}{l}\text { Practice } \\
\text { items }\end{array}$ & Statements & M \\
\hline 1 & 19 & I allow learners to evaluate their own speaking tasks by themselves. & 0.17 \\
\hline 2 & 22 & I work as a co-learner with the learners. & 1.43 \\
\hline 3 & 23 & Learners decide the learning environment. & 1.47 \\
\hline 4 & 9 & $\begin{array}{l}\text { Learning list varies from learners to learners according to their own interest area of } \\
\text { speaking. }\end{array}$ & 2.00 \\
\hline 5 & 14 & Assignments for learning speaking are different for different ability students. & 2.13 \\
\hline
\end{tabular}

\subsection{Discussion of the findings from qualitative data:}

This part of the study will bring together the data collected from the survey questionnaire with interview findings and that with the process principles of learner autonomy (Holec, 1979).

Several interview questions have been developed to seek feedback on the practices about learner autonomy and the teachers' use of those strategies in the English speaking classes. My aim is to bring together the data collected from the survey questionnaire with interview findings. The interview data findings will help to support the findings of the quantitative data.

\subsubsection{Teachers responses of the semi-structured telephone interview (Teachers' data about teachers' practice):}

It is already mentioned in the methodology section that semi-structured telephone interviews are done with five of the teachers among the survey respondents. Their responses (see appendix-2 for the questions including the basic areas of research) reveal their practices and views about the teachers teaching English speaking strategies.

For this study, teachers are mentioned as T1, T2, T3, T4 and T5. The teachers' responses are summarized below with each of the questions used in the telephone interview:

1. Are your students fully aware of their learning objectives? Do you think learners should decide the learning objective of themselves about their English speaking? If 'yes' why? If 'no', why not? 
The interview question conforms to the survey findings that teachers not always share the objectives to the learners. T1 says that in case of learning objectives, some learners know it but others don't know it. T1 sometimes explains the learning objectives but the unconscious and below average learners don't understand the objectives.

T1 thinks that deciding objective can work differently for different ability learners. Some learners can decide objectives as they have that courage, knowledge and ability to decide but the others can't do that. So, learning objective is mostly not decided by the learners. T1 also added that the scope of material also determines taking decision about learning objectives. T2 is also agreed about the learners not being aware of learning objectives. $\mathrm{T} 1$ agrees about deciding objectives by the learners as it will help them to enhance knowledge about their own weaknesses and abilities. T3 agrees that the learners are aware of learning objectives. T3 also adds that learning objectives should not be decided by the learners as $\mathrm{t} 3$ thinks they are unable to set appropriate objectives.

T4 says that sometimes the learners are aware of the learning objectives but most of the time they are not. T4 responses that learning objectives should not be decided by the learners as the perspective of our learning is teacher oriented. So, teachers should decide the learning objectives. T4 adds that the learners are not that much motivated to decide own objectives because they are dependent on the teachers. At the same T4 says that most of the time the learners are so poor in speaking English that they even cannot set objectives according to the standard of tertiary level of learning. T4 also admits in the interview that teachers always have to think the standard, quality and motivation of the learners. Moreover, they also need to think of the logistic supports those will be provided by the institution and later on decide the learning objectives for the learners. T5 admits that the learners become aware of their learning objectives after passing a short period of that course. In case of deciding objectives, it totally depends on the learners' quality. T5 thinks that good quality learners can decide their objectives by themselves but the bad ones are not allowed to decide objectives.

2. What should be the role of a teacher in an English speaking classroom? Will the teacher take responsibility of learners' learning speaking? Or, do you think a teacher should act as a guide and facilitator and gradually move the learners to independence from dependence? Justify your answer with appropriate reasons.

All the teachers (T1, T2, T3, T4 and T5) response in same manner for this question as they all agree that the teachers should work as facilitators in English speaking classes. They agree that they should not take all the responsibilities of language learning. Teachers and learners collaborative trial will lead the learners to be independent English speakers. Because, learning belongs to the learners, more involvement of learners will lower their fear in speaking.

3. Do you allow the learners to choose their learning materials for English speaking classes or do you make the learning lists by yourselves? If yes why? If no, why not?

In response to the question $\mathrm{T} 1$ and $\mathrm{T} 5$ are agreed about selecting speaking materials by themselves. Because, learners' are not that much qualified and according to their level weaknesses they can't choose the materials. Moreover, they think, teachers can only select material according to the perspective. While, the others (T2, T3 and T4) admit to select material collaboratively because, they believe, this collaboration creates an interactive and fruitful class. Interaction also enhances success in learning as it creates a comfortable environment.

4. Do you decide the English speaking activities for the learners? Or, do your learners decide their learning strategies? Justify your answer with appropriate reasons.

T1 admits selecting materials by the teachers only. Because, the teachers say that the learners' efficiency, level and ability don't allow the learners to select their own strategies. T1 also supports teachers' selection about the materials as there are needs for logistic support and scope. T3 also talks about the teachers' maximum involvement in selecting learning strategies. On the contrary to these opinions, T2, T4 and T5 believe in collaborative decision about selecting strategies. Because, they think the learners involvement in selecting strategies will help them to increase their interest and attachment to the tasks. This comfortable situation will make fruitful learning. Here, the noteworthy point is, though T4 believes in collaboration but they think teachers should mostly select strategies. The reason is, if the learners are asked to select strategies, most of the time they are indecisive and confused about what to do.

5. Do you think students should be allowed to evaluate their own speaking performances in the class? If yes why? If no, why not?

A sort of practice works in almost all the teachers (T1, T2, T3 and T4) to allow the learners to evaluate their own speaking tasks. Because, all of the teachers believe that this type of evaluation increases the learners' responsibility to learning. At the same time it can be reliable, easy to cope up and can create motivation also. Peer evaluation also helps to make the evaluation process easier and effective which can bring noteworthy improvement.

On the other hand, the response from T5 is quite different from others as T5 thinks that peer evaluation can create shyness among the learners where it becomes a prestige issue. In some cases, peer evaluation can create jealousy among the learners. It can also be a matter of hazard. 
6. Do you create a relaxing and comfortable environment in the class? Do you allow the learners to differ and challenge you in opinion?

Most of the teachers (T1, T2, T4 and T5) allow the learners to debate them in opinion. Because, they think this comfortable environment will encourage the learners to talk more in English as they are teaching English speaking. The teachers also believe that less fear will improve learning.

In case of this question, there is a diverged opinion as T3 admits not to allow the learners to debate with the teachers. According to T3, debate will create unnecessary comments which will degrade the teachers' image.

\section{Implications of the Findings}

The study brings out the actual practice in a tertiary level English speaking class in the private universities in Bangladesh. Therefore, the study may clearly have positive implication for both the parties' teachers and learners including all the institutions involved in the pedagogy of English in Bangladesh. From this research work, teachers will get scope for further study. They will also know about the benefits of learner autonomy and to what extent it can be useful for teaching English. Furthermore, language teachers will get further scope to rethink and revise their probable roles to teach English effectively. Teachers have more implications as they will have clear understanding about the dos and don'ts of their teaching.

This research can be a very good feedback for the teachers to modify materials, method, selecting objective, environment, teacher-learner relationship and environment according to the principles of autonomous learning. Finally, institutions also will be aware of giving enough logistic support to the classrooms to make them effective ones. Modern technology is a great support in language teaching, this truth will be unfolded for not only the English speaking classes rather to develop other skills in other classes.

Speaking in English is presently one of the major demands because of several vital reasons as they were mentioned before. This study will help all to improve the teaching and learning process because adult learning is quiet difficult for some unavoidable matters. Thoughts and study on learner autonomy can create positive effect not only in the classroom but also outside the classroom. What a learner feels about his learning is beyond the capacity of a teacher. But, autonomous learning can bring some positive matters for the learners' involvement in learning. Thus, the teaching-learning process would be facilitated more than what is existing now.

\section{Conclusion}

This significant study unfolds that the teachers of most of the private universities do not follow learner autonomy at the tertiary level in English speaking classes. Though they have some autonomous practice in English speaking classes but that is very less. But, it is really hard to generalize that it is a common picture in all the private universities in Bangladesh. This needs a large scale survey including more private universities from different regions of Bangladesh. It is observed that thou the teachers are not practicing learner autonomy, they have support for it which can be enhanced through more logistic supports provided by the institutions. Teachers can also improve the matters in their hands like good and supportive behavior, showing tolerance, allowing the learners to choose and to participate equally in class activities of their own interest. It is a limitation of the present study that data were collected only from teachers due to time shortage. If the learners were included we could get into their insight and thought regarding their awareness and choice about learner autonomy and their opinion about the above findings. Yet, the present study carries immense importance because the findings and suggestions drawn in the study would contribute positively to the improvement of English Language teachinglearning at the tertiary level of the private universities of Bangladesh. Moreover, this study has huge scope to inspire some other researchers to investigate learner autonomy in the perspective of Bangladesh in future with vast positive impact.

Bibliography:

[1]. Ashraf, M.A., Ibrahim, Y and Joarder, M.H.R. (2009). Quality Education Management at Private Universities in Bangladesh: An Exploratory Study. Journal Pendidik Dan Pendidikan, Jil. http://web.usm.my/education/publication/JPP24 MohammadAshraf pdf

[2]. Baumgartner, C. Merriam (2007). Learning in Adulthood.

[3]. Benson, P. (2001). Teaching and Researching Autonomy in Language Learning. Harlow: Longman

[4]. Brown, H.D. (1994). Principles of Language Learning and Language Teaching. NJ: Prentice-Hall.

[5]. Crookes, G. (2003). A Practicum in TESOL. Cambridge: Cambridge University Press.

[6]. Crystal , D. (1997). English as a Global Language. UK: Cambridge University Press.

[7]. Dam, L. (1995). Learner Autonomy 3: From Theory to Classroom Practice. Dublin: Authentik.

[8]. Holec, H. (1979). Autonomy and Foreign Language Learning. UK: Pergamon Press Ltd.

[9]. Jefferson, G. (ed.). (1992). Lectures on Conversation. Oxford: Blackwell.

[10]. Lamb, T., \& Reinders, H. (Eds.). (2008). Learner and Teacher Autonomy: Concepts, Realities, and Responses. Amsterdam: John Benjamins.

[11]. Larsen-Freeman, D. (2000). Techniques and Principles in Language Teaching. Oxford: Oxford University Press.

[12]. Little, D. (1991). Learner Autonomy 1: Definitions, Issues and Problems. Dublin: Authentik. 
[13]. Nunan, D. (Ed.) (2003). Practical English Language Teaching.New York: Mc Graw-Hill

[14]. Oskarsson, M (1998). Approaches to Self-Assessment in Foreign Language Learning Program, Oxford.

[15]. Palfreyman, D. and R. C. Smith. (Eds.). (2003). Learne Autonomy Across Cultures: Language Education Perspectives. Basingstoke: Palgrave Macmillan.

[16]. Rahman, S. (2005). Orientation and Motivation in English Language Learning: A Study of Bangladeshi Students at Undergraduate Level. Asian EFL Journal: English language Teaching and Research Articles. 7 (1). n. d. 22 April 2009. $<$ http:www.asian-efl-journal.com/march 05 sr.php $>$

[17]. Richards, C.J. \& Rodgers, S.T. (2002). Approaches and Methods in Language Teaching. UK: Cambridge University Press.

[18]. Rogers, C. (1969). Freedom to Learn. Columbus, Ohio: Merill.

[19]. Schutz, R. (2007). Stephen Krashen's Theory of Second Language Acquisition. 2 July 2007. 22 April 2009

[20]. Stevick, E.W. (1090). Humanism in Language Teaching: A Critical Perspective. Oxford: Oxford University Press.

[21]. Ushioda, E. (1996). Learner Autonomy 5: The Role of Motivation. Dublin: Authentik.Wallace, M. (1991). Training foreign language teachers: A reflective approach. Cambridge: Cambridge University Press. 